\title{
Hereditary Hemorrhagic Telangiectasia, a Vascular Dysplasia Affecting the TGF- $\beta$ Signaling Pathway
}

\author{
Africa Fernández-L, Francisco Sanz-Rodriguez, PhD, Francisco J. Blanco, \\ Carmelo Bernabéu, PhD and Luisa M. Botella, PhD
}

\begin{abstract}
Hereditary hemorrhagic telangiectasia (HHT) is caused by mutations in endoglin (ENG; HHT1) or ACVRL 1/ALK1 (HHT2) genes and is an autosomal dominant vascular dysplasia. Clinically, HHT is characterized by epistaxis, telangiectases and arteriovenous malformations in some internal organs such as the lung, brain or liver. Endoglin and ALK1 proteins are specific endothelial receptors of the transforming growth factor (TGF)- $\beta$ superfamily that are essential for vascular integrity. Genetic studies in mice and humans have revealed the pivotal role of TGF- $\beta$ signaling during angiogenesis. Through binding to the TGF- $\beta$ type II receptor, TGF- $\beta$ can activate two distinct type I receptors (ALK1 and ALK5) in endothelial cells, each one leading to opposite effects on endothelial cell proliferation and migration. The recent isolation and characterization of circulating endothelial cells from HHT patients has revealed a decreased endoglin expression, impaired ALK1- and ALK5-dependent TGF- $\beta$ signaling, disorganized cytoskeleton and the failure to form cord-like structures which may lead to the fragility of small vessels with bleeding characteristic of HHT vascular dysplasia or to disrupted and abnormal angiogenesis after injuries and may explain the clinical symptoms associated with this disease.
\end{abstract}

Keywords: Actin cytoskeleton; ALK1; Angiogenesis; Endoglin; Endothelial cells; Hereditary hemorrhagic telangiectasia; TGF- $\beta$ pathway; Vascular dysplasia

\section{$\mathrm{T}$}

\section{he Disease and its Clinical Manifestations}

Hereditary hemorrhagic telangiectasia (HHT), or Rendu-Osler-Weber syndrome, is an autosomal dominant vascular disease characterized by localized angiodysplasia. This is manifested as epistaxis, mucocutaneous and gastrointestinal telangiectases, and arteriovenous malformations in the pulmonary, cerebral or hepatic circulation. ${ }^{1}$ The prevalence is on average between 1 in 5,000 to 1 in 8,000 , although it is higher in some regions, such as the Jura region in France, Funen island in Denmark and certain Caribbean islands in the Netherland Antilles. ${ }^{2-4}$

HHT patients are diagnosed according to the consensus clinical criteria of Curaçao, which were established by the Scientific Advisory Board of the HHT International Foundation ${ }^{5}$ (table 1). The presence of three out of four criteria (spontaneous recurrent epistaxis, cutaneous telangiectases, visceral involvements and familiar heredity) is considered as a positive diagnosis for HHT, while the

Reprint Requests: Africa Fernández-L, Centro de Investigaciones Biologicas (CSIC), Ramiro de Maeztu, 9, Madrid 28040, Spain, Tel: 349/83731I2; Fax:34915360432,Email: africa@cib.csic.es

Accepted: October 6, 2005 presence of only two criteria indicates a suspected diagnosis. The genetic diagnosis by DNA sequencing has not as yet been considered among these criteria, but may be in the future. Recently, Cohen et $\mathrm{al}^{6}$ have shown that a genetic screening strategy with targeted clinical protocol is more economically attractive than the conventional clinical screening and results in a reduction in the number of clinical tests for family members who do not have HHT.

The severity and age of onset in the different manifestations vary considerably, even among the members of the same family making diagnosis very difficult. It is especially critical in young patients since the penetrance of the disease is age-dependent. ${ }^{7-9}$ The mechanisms of the pathogenicity are not completely understood. However, the discovery of two genes involved in the disease and their functional link has thrown light on the mechanisms leading to vessel alterations. 
Table 1. Criteria for HHT diagnosis

\begin{tabular}{ll}
\hline Clinical diagnosis & Curaçao criteria \\
\hline Epistaxis & Spontaneous recurrent nosebleeds \\
Telangiectases & Red spots in oral mucosa and skin \\
Familiar inheritance & Autosomal dominant \\
Internal organ involvement & $\begin{array}{l}\text { Lung, brain, spinal cord, and liver } \\
\text { arteriovenous malformations }\end{array}$ \\
Molecular & DNA sequencing for ENG and ALK1. \\
& Also in some cases where no \\
mutations are found in the two main \\
loci of HHT, DNA sequence of \\
MADH4 and BMPRII.
\end{tabular}

$\mathrm{HHT}$, hereditary hemorrhagic telangiectasia. ENG, endoglin gene. ALK1, activin receptor-like kinase 1. MADH4, tumor suppressor protein, DPC4/Smad4. BMPRII, bone morphogenetic protein receptor 2.

\section{Endoglin and ALK1 are the Genes Mutated in HHT}

The first locus to be identified as mutated in HHT patients was localized on chromosome 9q33-3410,11 by linkage studies. However, from the beginning, Shovlin et al ${ }^{11}$ described genetic heterogeneity in the origin of HHT, as she found a HHT family not linked to this 9q locus. Independently, Fernandez-Ruiz et al ${ }^{12}$ mapped endoglin to chromosome 9q33-34 by in situ hybridization. Then, McAllister et al ${ }^{13}$ showed that $E N G$ was in fact the HHT gene and that mutations in $E N G$ gave rise to type 1 HHT (HHT1, OMIM 131195). After the first evidence of genetic heterogeneity in HHT, different groups reported non-ENG-linked HHT families. Genetic linkage studies of those families placed the second locus on the $12 \mathrm{q}$ region. Subsequently, three families linked to $12 \mathrm{q}$ showed mutations in the ALK1/ACVRL1 locus (activin receptor-like kinase 1, OMIM 600376) gene mapped on 12q11-q14. This locus was identified as the second cause of HHT, in this case denoted type 2 HHT (HHT2). ${ }^{14}$ Interestingly, patients with clinical characteristics of HHT without mutations in ENG or $A L K 1$ have also been reported, suggesting that other genes might be linked to HHT. ${ }^{15,16}$ In this sense, it was found that mutations in bone morphogenetic protein receptor II (BMPRII) give rise to pulmonary primary hypertension with a similar phenotype to HHT. ${ }^{17-19}$ Moreover, Gallione et al ${ }^{20}$ recently reported that mutations in MADH4 (Smad 4) can cause a syndrome consisting of both juvenile polyposis and HHT phenotypes. The proteins encoded by these different mutated loci in HHT patients share common functional roles, all of which belong to the transforming growth factor (TGF)- $\beta$ signaling pathway (table 2). Recently a third locus, $5 \mathrm{q} 31.3-5 \mathrm{q} 32$, has been described as responsible for the HHT3.21

HHT1 and HHT2 are Linked to Mutations in ENG and ALK1

Clinically, both HHT1 and HHT2 are indistinguishable, although some studies have claimed a lower penetrance with a later onset in HHT2 versus a higher frequency of pulmonary arteriovenous malformations in HHT1.22-24 Also, the predominance of HHT1 or HHT2 appears to correlate with geographical location. Thus, while HHT1 is more abundant in North America, Canada ${ }^{23,25}$ and the northern European populations, ${ }^{26}$ HHT2 is predominant in the Mediterranean countries such as Italy, ${ }^{24,27}$ France $^{28}$ and Spain. ${ }^{29}$

To date, $136 E N G$ and 105 ALK1 mutants have been found. ${ }^{30}$ HHT1 associated mutations have been reported in the first 12 exons of $E N G$ corresponding to the extracellular domain ${ }^{27,28,31}$ (figure 1). This number is continuously increasing, which indicates that any nucleotide could be mutated, except probably those encoding for the transmembrane region (exon 13) or cytoplasmic domain (exon 14). Mutations include deletions (small or those encompassing more than one exon), insertions of one or several bases, nucleotide substitutions and intron splice junction mutations leading, in most cases, to unstable RNA or proteins not expressed on cell surface.

More than 100 mutations have been described for $A L K 1$ with a predominance of missense mutations in the intracellular kinase domain (exons 7 and 8). ${ }^{32}$ In contrast, HHT1/ENG most frequently contains missense mutations with deletions and insertions being less common and long DNA reorganizations being very rare. Mutations in HHT1/ENG are especially concentrated in exons 3, 4, 7, 8 and 9. However, all exons may be affected (figure 1).

\section{The TGF- $\beta$ Signaling Pathway}

TGF- $\beta$ signals through a heteromeric complex of type I (RI) and type II (RII) transmembrane serine/threonine kinase receptors (figure 2). Although the core of the TGF- $\beta$ receptor complex is formed by the association of RI and RII, it may also contain auxiliary receptors such as endoglin and betaglycan. ${ }^{33}$ First, TGF- $\beta$ binds RII with a high affinity. This TGF- $\beta /$ RII complex then recruits RI. Once the heteromeric complex TGF- $\beta /$ RII/RI is formed, ${ }^{34}$ a domain of RI is phosphorylated by RII. ${ }^{35}$ This phosphorylation of serine/threonine residues leads to RI

Table 2. Loci and genes involved in HHT

\begin{tabular}{|c|c|c|}
\hline Gene & Chromosomal locus & Type of disease \\
\hline ENG & $9 q 33-q 34.1$ & $\mathrm{HHT} 1$ \\
\hline ACVRL1/ALK1 & $12 q 11-q 14$ & HHT2 \\
\hline MADH4 & $18 q 21.1$ & JPHT \\
\hline BMPRII & $2 q 33$ & $\mathrm{PPH}$ \\
\hline$?$ & $5 q 31.3-5 q 32$ & НHТЗ \\
\hline
\end{tabular}




\section{Endoglin}
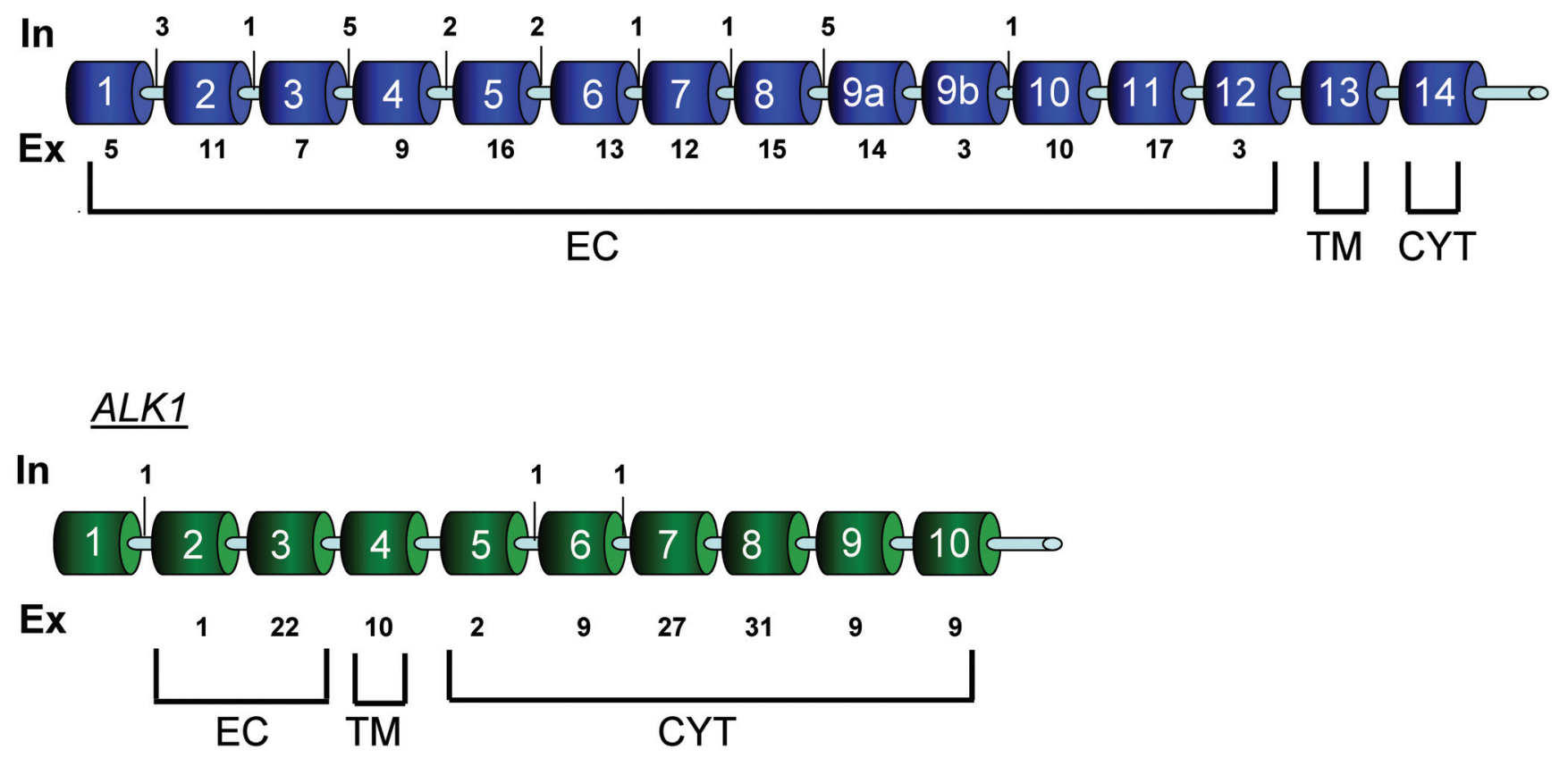

Figure 1. Mutations found in the different introns (In) and exons (Ex) of ENG and ALK1. Exons are represented by cylinders (numbered 1-14 in ENG and 1-10 in ALK1) with bars between the exons representing introns. Figures below the exons and above the introns represent the number of mutations found in each exon or intron, respectively. Protein domains of Endoglin and ALK1 are indicated under the exons by EC (extracellular domain), TM (transmembrane domain) and CYT (cytoplasmic domain). Adapted from Abdallà and Letarte. 30

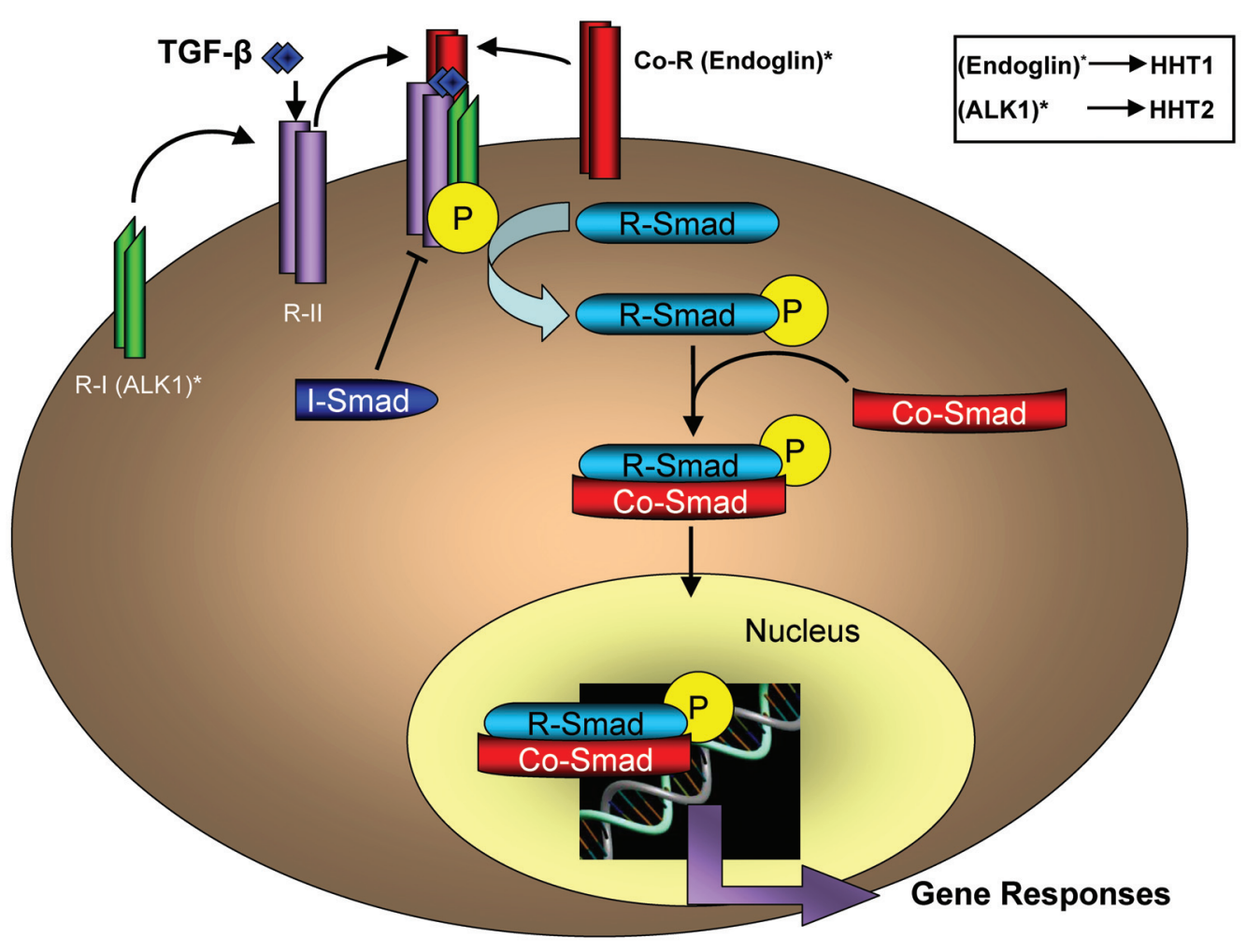

Figure 2. TGF- $\beta$ signaling cascade. TGF- $\beta$ binds to RII and the resulting complex recruits and phosphorylates RI. The receptor complex also contains the auxiliary receptor endoglin. Activated RI transmits the signal to the nucleus through the Smad family of co-activators. First, RI phosphorylates R-Smads which then associate with Co-Smads, namely Smad4. The R-Smad/Co-Smad complex translocates to the nucleus to regulate TGF- $\beta$ responsive genes. R-Smad, receptor dependent Smad; I-Smad, inhibitory Smad; Co-Smad, collaborator Smad; ALK1, R-I mutated in HHT2; Endoglin, auxiliary TGF- $\beta$ receptor mutated in HHT1. 


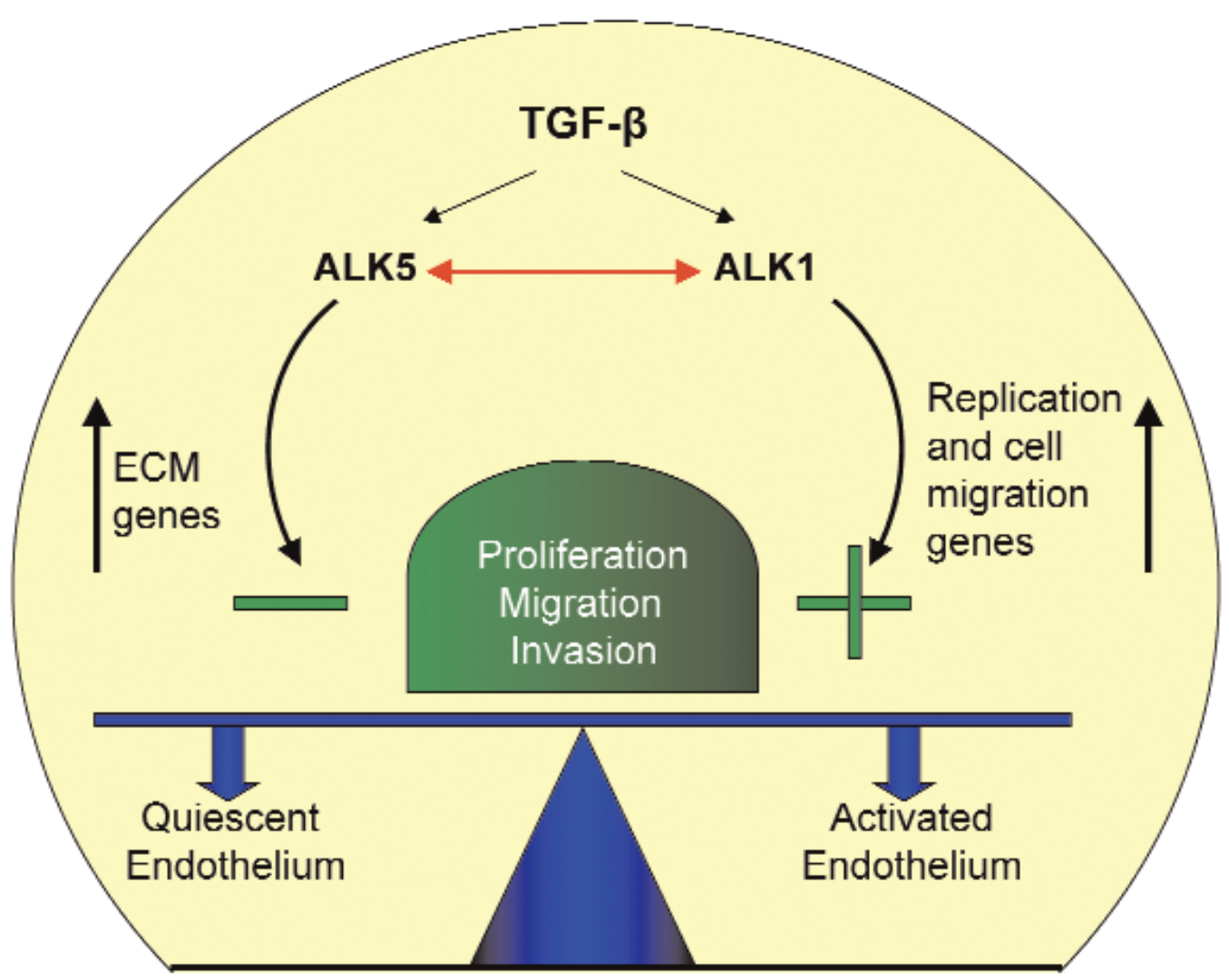

Figure 3. Balanced signaling through the TGF- $\beta$ receptors type I, ALK1 and ALK5, in endothelial cells. When the TGF- $\beta$ response is transmitted via ALK1, the proliferation and migration genes are stimulated giving rise to the activated phase of angiogenesis (activated endothelium). However, when the ALK5 pathway is predominant, the genes coding for extracellular matrix (ECM) components are upregulated and the proliferation and cell migration genes are repressed, leading to a quiescent endothelium. In addition, ALK1 and ALK5 functionally regulate each other. Adapted from Lebrin et al.44

activation, in turn propagating the signal through a cascade of intracellular effectors which belong to the Smad protein family. There are three different types of Smads: receptor regulated (R-Smads), common mediator (Co-Smads) and inhibitory (I-Smads) Smads. ${ }^{35,36}$ R-Smads like Smad1, Smad2, Smad3, Smad5 and Smad8 are phosphorylated and activated by RI and these activated R-Smads bind subsequently to the Co-Smad, Smad4. The R-Smad/Co-Smad complexes translocate to the nucleus where they contribute to the transcriptional activation of target genes. The I-Smads (Smad6 and Smad7) prevent R-Smad phosphorylation by competing with R-Smads for receptor interaction ${ }^{37}$ through recruitment of ubiquitin ligases to the activated receptor leading to its proteosomal degradation ${ }^{38}$ or by recruiting phosphatases that inactivate RI. ${ }^{39}$

All the genes implicated in HHT code for proteins belonging to the TGF- $\beta$ signaling pathway. Therefore, understanding this pathway is crucial for establishing the relationship between genes affected by mutation in HHT patients and the disease. BMPRII (bone morphogenetic protein receptor-2) and ALK1 belong to the RII and RI families, respectively. Smad4 belongs to the Smad effectors family and endoglin (or CD105) is an endothelial accessory receptor of TGF- $\beta$. Endoglin is a $180 \mathrm{kDa}$ homodimeric transmembrane glycosylated protein that binds several members of the TGF- $\beta$ superfamily ${ }^{40-42}$ and interacts with both RI and RII, ${ }^{43}$ and in particular with the two different types of RI, ALK1 and ALK5,44,45 expressed by endothelial cells. ${ }^{46}$

\section{Balance Between TGF- $\beta / A L K 1$ and TGF- $\beta / A L K 5$ in Endothelial Cells}

HHT is a vascular disease in which endothelial cells appear to be the primary cell target affected. The genes, Smad4 and BMPRII, mutated in HHT are expressed in a broad range of cell types (including endothelial cells), whereas $E N G$ and $A L K 1$ are mainly restricted to the endothelium. The endothelial TGF- $\beta$ system is characterized by the coexistence of two types of RI, the ubiquitously expressed ALK5 and the endothelium specific ALK1. These two RIs signal through different R-Smads; while ALK1 signals by Smad1/Smad5, ALK5 prefers Smad2/Smad3. ${ }^{47}$ The existence of the two types of RI pathways activated by the same ligand, TGF- $\beta$, poses the problem of the mechanism of tuning between both cascades. This problem has been addressed by several groups $^{44-48}$ and has been recently reviewed. ${ }^{49-51}$ Goumans et al 46,47 observed that ALK5 deficient endothelial cells were defective in both TGF- $\beta$ /ALK5 and TGF- $\beta$ /ALK1 responses, demonstrating that the kinase activity of ALK5 was essential for an appropriate ALK1 activation. The coexistence of ALK1 and ALK5 is then necessary for a proper TGF- $\beta$ signaling in 
endothelial cells. However, ALK1 and ALK5 may induce opposite cellular responses: TGF- $\beta$ /ALK1 induces endothelial cell migration and proliferation, while TGF- $\beta$ /ALK5 inhibits these effects and promotes extracellular matrix deposition. ${ }^{52}$ These two counteracting effects correspond to the two distinct phases of the angiogenic process: quiescence (absence of proliferation, extracellular matrix deposition, recruitment of smooth muscle cells and stabilization of vessels) versus activation (proliferation and migration of endothelial cells to form new vessels) (figure 3). This antagonism is exerted at the molecular level via R-Smads, since ectopic overexpression of Smad5 potentiates the ALK1 inhibitory effect on ALK5 induced responses, while overexpression of Smad3 attenuates this effect. The opposite actions between ALK1 and ALK5 in endothelial cells are the basis for an intricate mechanism of equilibrium controlled by a fine TGF- $\beta$ tuning. Thus, low doses of this cytokine stimulate endothelial cell proliferation and migration via the ALK1/Smad1/Smad5 route, while high doses of TGF- $\beta$ inhibit these responses and favor the ALK5/Smad2/Smad3 pathway. ${ }^{46-48}$

\section{The Haploinsufficiency Model in HHT}

HHT disease is manifested in a heterozygous condition and no conclusive reports on living homozygous individuals are known. Some rare cases were reported in the past when the clinical diagnosis criteria and the responsible genes for HHT were not clearly established. Karabegovic et al ${ }^{53}$ did not find any homozygous individuals in a large consanguineous Arab family. Therefore, the lethality of the homozygous condition is generally accepted. Moreover, the lethality of the homozygous $E N G$ and $A L K 1$ knockout mice, which die in the embryonic stage at mid-gestation, supports this conclusion. ${ }^{54-57}$

Two hypothetical models have been considered in the literature to explain the manifestation of a disease in a heterozygous condition. One is the dominance of mutations in ENG or ALK1 genes. The other one is the haploinsufficiency model, meaning that most mutations lead to unstable transcripts or unstable proteins that do not reach the membrane surface. Consequently, the population of functional endoglin or ALK1 molecules would be below the necessary threshold to meet the needs of the endothelial cells. Early on, McAllister et al ${ }^{58}$ supported a dominant negative model for $E N G / H H T 1$ based on the clustering of the former $E N G$ mutants in the extracellular domain between exons 4 and 11. They thought that the truncated or deleted proteins would be translated and could out-compete the wild type endoglin function. However, in the following years several authors reported mutations causing either the transcript or the protein to be unstable which supports the haploinsufficiency model. ${ }^{59}$ Gallione et al ${ }^{60}$ found an $E N G$ null allele resulting from a missense mutation changing the translation start codon ATG to ACG. As no other consensus start exists for $E N G$, the mutant allele could not be translated. The existence of many different mutations spread throughout the extracellular domain of $E N G$ (exons 1-12), and causing a common clinical phenotype, favors the haploinsufficiency model particularly for $E N G / H H T 1$. This model has also been extended to $A L K 1 / \mathrm{HHT} 2$.

Mutant expression patterns of endoglin and ALK1 have been studied in multiple models, including 1) human umbilical vein endothelial cells (HUVECs), 2) site directed mutagenesis of the corresponding cDNAs and in vitro expression by transient transfection in COS cells, or 3) vaccinia virus infection of mammalian cells without endogenous expression of endoglin or ALK1.23,25,32,61-64 In general, studies performed in HUVECs derived from newborns carrying endoglin mutations showed a reduction in surface expression of endoglin compatible with the haploinsufficiency model. Similar endoglin levels were demonstrated in activated monocytes coming from $E N G / \mathrm{HHT} 1$ patients, i.e. a reduction of endoglin compared to the control activated monocytes. Regardless of the type of mutation (either missense or nonsense leading to early truncation), HUVECs and monocytes from HHT1 patients showed much lower endoglin levels than healthy controls. $23,30,60,61,64$ When endoglin mutants were expressed in vitro, in most cases protein products were not detected. Most mutations either gave rise to unstable mRNA or translated proteins were not fully glycosylated and therefore were not expressed at the surface of the cells. ${ }^{61,62,65}$ In only one case, an endoglin mutant had a dominant negative effect in vitro by sequestering wild type endoglin forms. ${ }^{65}$ However, these results have not been reproduced by endogenous expression in HHT monocytes or HUVECs.

In the case of $A L K 1$ and following conclusions drawn from $E N G$, the haploinsufficiency model has also been confirmed in several HHT2 mutants. However, most ALK1 mutations lead to amino acid substitutions (about 60\% are missense mutants), suggesting the possibility that these mutants could be translated. Investigation into the processing and traffic of these products in HUVECs or in transfected cell ${ }^{23}$ has shown that at least three of them are able to reach the cell membrane. Among them, two of these missense mutations were identified as dominant-negative candidates. They are located in the GS domain (D179A) and in the NANDOR box (K487T) and were found in families with a risk of developing HHT-related pulmonary primary hypertension. ${ }^{17,18}$ According to the 3D prediction model for ALK1,32 substitutions affecting the kinase domain could destroy conserved motifs and key hydrogen bonds or destabilize amino acidic structures interfering with the catalytic activity.

\section{Animal Models for HHT}

$E N G$ and $A L K 1$ knockout mice were obtained by several groups between 1999 and 2000 for $E N G^{54-57}$ and for $A L K 1.48,66-68$ Since neither $E N G$ nor $A L K 1$ null mice showed problems in the formation of the early capillary plexus in the yolk sac or the embryo, it is believed that they are not involved in vasculogenesis. Nonetheless, these null embryos (eng-/eng-) were lethal, dying in the uterus at around 10.5 days of embryonic life due to improper mature 
vascularization, heart valve formation, septation and angiogenesis from E9.0 leading to dilated vessels prone to rupture and hemorrhages. This phenotype is similar to that of the knockout mice for other TGF- $\beta$ signaling network genes, i.e., ALK5, T $\beta$ RII and TGF- $\beta 1$, although the latter shows, in addition, a failure in the early vasculogenesis. Unfortunately, the incomplete expression of the disease in most strains is a handicap for the murine model. In fact, Bourdeau et al ${ }^{56}$ observed strain-dependent differences in the manifestation of the symptoms and actually HHT clinical symptoms similar to the human disease could only be developed in the strain Ola/129. The influence of epigenetic factors and other modifier genes is an added difficulty to the murine model. ${ }^{69,70}$ Furthermore, the pathogenicity of individual mutations cannot be studied in this model.

While a better animal model for HHT arises, successful vascular-specific gene delivery expression of human endoglin in normal mouse and rats has been accomplished..$^{71}$ Thus, the promoter of the endothelial gene $I C A M-2$ was used to generate transgenic animals which demonstrated endothelial expression of endoglin. Also, the promoters of the human endothelial genes, $E N G$ and $I C A M-2$, were inserted upstream of the human $E N G$ cDNA, and the resulting plasmid expression vectors were systemically or locally delivered, demonstrating endoglin expression in the vessel walls of liver, lung and skin. ${ }^{71}$ These gene transfer experiments represent a preliminary step in the treatment of HHT by gene therapy.

\section{Cellular Models for HHT}

HUVECs have been the main source of cells to study HHT disease at the molecular level. The main problem is the scarce availability of these cells from affected newborns and the fact that the symptoms of the disease are not yet present in most cases. Only in a few cases of HHT pregnancies have HUVECs been used as a tissue source for the direct study of ENG/ALK1 mRNA and protein levels. ${ }^{23,61,64}$ Since endothelial cells from adult HHT patients are currently very difficult to obtain, the use of activated monocytes from peripheral blood represents an alternative method to measure levels of endoglin in adult patients clinically diagnosed for HHT. Interestingly, endoglin is upregulated during the process of activation of monocytes. ${ }^{72}$ This property was used in early studies to quantify the relative endoglin levels in monocytes derived from HHT1 patients. ${ }^{61,64}$ More recent studies by Sanz-Rodriguez et $\mathrm{al}^{73}$ have found that endoglin upregulation is impaired in the monocyte-macrophage transition in both HHT1 and HHT2 patients and that the degree of upregulation is age-dependent in those patients.

The downregulated expression of endoglin in activated monocytes derived from HHT2 patients contrasts with previous reports 23,64 in which endoglin levels were unaffected in HHT2 patients. This apparent discrepancy is likely explained by the different experimental methods used to determine the levels of endoglin and the age factor. Accordingly, in HHT2, endoglin levels of the younger affected members (from 12 to 22 years old) are not different from their age-matched controls and endoglin expression deficiencies become evident only in older family members ( $>45$ years old). ${ }^{73}$ Taking into account the age-dependence of endoglin expression, it is not surprising to find that in HHT2 HUVECs (newborns, age 0), the amount of endoglin is found to be close to normal levels. ${ }^{64}$ The results with monocytes have been recently confirmed by our group in a large study encompassing 17 HHT Spanish families with approximately 100 patients. ${ }^{29}$ An interesting conclusion of these studies is the endoglin deficient upregulation in either HHT1 or HHT2 activated monocytes. This fact opens new molecular insights in the study of HHT pathogenicity. Also, if there is an endoglin deficiency in activated monocytes of HHT2 as well as HHT1 patients, what would happen in HHT endothelial cells?

\section{Circulating Endothelial Cells as a New Cellular Model for HHT}

Adult endothelial cell cultures can be obtained following previously described methods 66,67 that allow the isolation of blood outgrowth endothelial cells (BOECs). These are functionally mature endothelial cells ${ }^{74,75}$ able to be incorporated in vivo into the vascular endothelium and have been successfully used for gene therapy studies. ${ }^{75}$ Fernández-L et al ${ }^{76}$ have shown for the first time the characterization of pure cultures of HHT BOECs from Spanish patients with known clinical diagnosis and identified mutations in endoglin or ALK1. These cells have been used to investigate the molecular basis for the disease. Cells from HHT patients were characterized as mature endothelial cells by positive staining with endothelial specific antibodies against PECAM-1, endoglin, VE-cadherin, ALK1, von Willebrand factor (vWF) and Flk-1(VEGFR-2) (figure 4) and negative staining for the endothelial precursor marker CD133, for the monocyte marker CD14 and for the fibroblast surface antigen 1B10 (SIGMA). HHT cells showed different morphology compared to controls having a bigger size in many cases, especially in HHT1 cells. Flow cytometry and western blot analysis supported the decreased amounts of endoglin in HHT1 endothelial cells compared to controls, but endoglin was also significantly reduced in six different HHT2 endothelial cell cultures. Hence, endoglin deficiency seems a common characteristic for HHT1 and HHT2 cells and occurs both in activated monocytes and ECs.

\section{Involvement of ALK1 in ENG Gene Expression of HHT2 BOECs}

The downregulated expression of endoglin in HHT2 patients suggests the involvement of ALK1 in $E N G$ gene expression. Since $E N G$ expression is increased by TGF- $\beta^{77,78}$ and ALK1 is a TGF- $\beta$ signaling RI, it is tempting to hypothesize the impact of ALK1 signaling on the ENG promoter. In fact, Fernandez-L et al ${ }^{76}$ have shown that mutations of $A L K 1$ lead to an improper endoglin upregulation in HHT2 BOECs. Endothelial cells from healthy donors were co-transfected with a reporter $E N G$ promoter construct and expression vectors coding for different versions of the ALK1 kinase. A constitutively active kinase form of ALK1 (Q201D) doubled 
the transcriptional activity of the $E N G$ promoter and a dominant negative version (ALK1, K229R) decreased the activity of the endoglin promoter by one-half. Interestingly, ALK1 R374W harboring the mutation of an HHT2 family was able to inhibit approximately $50 \%$ of the activity of the $E N G$ promoter. In summary, endoglin and ALK1 are tightly linked. ALK1 not only cooperates with endoglin in endothelial TGF- $\beta$ signaling, but also transcriptionally regulates endoglin levels.

\section{ALK1/TGF- $\beta$ and ALK5/TGF- $\beta$ Pathways are Reduced in HHT BOECs}

Since endoglin cooperates with the TGF- $\beta$ /ALK1 pathway, but interferes with the TGF- $\beta /$ ALK- 5 route, 44,45 both TGF- $\beta$ signaling pathways were examined in HHT BOECs using specific reporters. ${ }^{76}$ Both ALK1/TGF- $\beta$ and ALK5/TGF- $\beta$ pathways are active in BOECs from normal donors, but both TGF- $\beta$ pathways are seriously affected in HHT derived BOECs. As expected from the endoglin/ALK1 cooperation, the TGF- $\beta$ response of the ALK1-dependent reporters was impaired in HHT cells. Surprisingly, the ALK5-dependent TGF- $\beta$ pathway was significantly reduced in these cells, supporting the previous observation by Lebrin et $\mathrm{al}^{44}$ in mouse endothelial cells from $\mathrm{eng}^{+} / \mathrm{eng}^{-}$embryos. These experiments show that responses of HHT endothelial cells to TGF- $\beta$ are severely compromised and limited and, consequently, their regulated involvement in the angiogenic process must be affected (e.g., proliferation, migration, tube formation, extracellular matrix deposition and pericyte/smooth muscle cell recruitment). Intriguingly, in a recent paper, ${ }^{79}$ it has been shown that null eng-/engendothelial cells from 8.5 day old embryos are responsive to TGF- $\beta$ and can proliferate faster in contrast to mouse eng ${ }^{+} /$eng $^{-}$endothelial cells. ${ }^{44}$

ALK5 pathway is diminished in HHT BOECs and a previous report also showed a significant reduction in the levels of ALK 5 in eng ${ }^{+} /$eng- mouse embryonic cells. ${ }^{44}$ To explain this phenomenon, Lebrin et $\mathrm{al}^{44}$ postulated that ALK5 is downregulated as a cell adaptation response to compensate for a decreased endoglin/ALK1 expression in HHT cells. Supporting this view, the levels of ALK5 RNA transcripts are decreased by $80 \%$ in HHT1 and HHT2 compared to control endothelial cells. ${ }^{76}$

The mechanism leading to ALK5 downregulation in HHT endothelial cells is the consequence of a transcriptional modulation by $A L K 1 / E N G$. Thus, the $A L K 5$ promoter is

\section{ENDOGLIN (HHT1)}
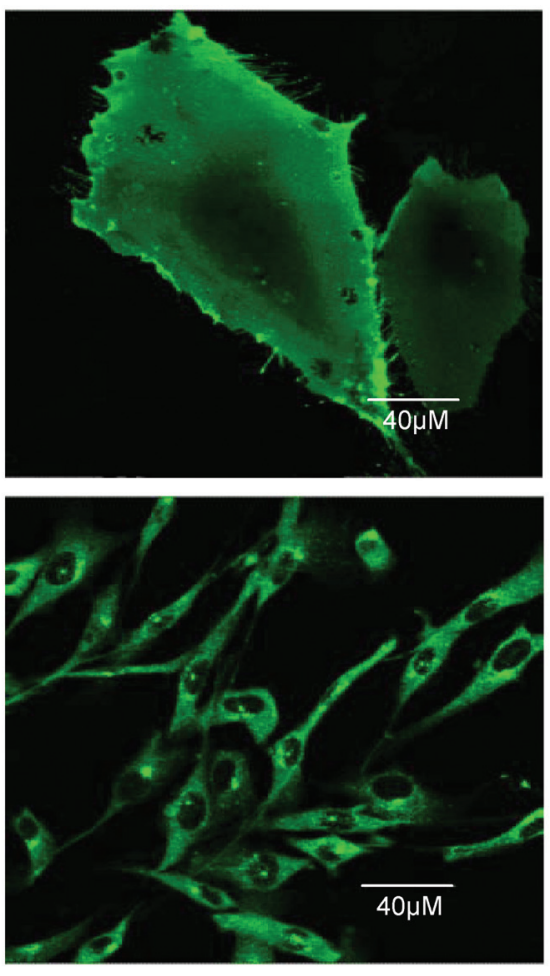

v-WF (HHT2)
ALK-1 (HHT2)
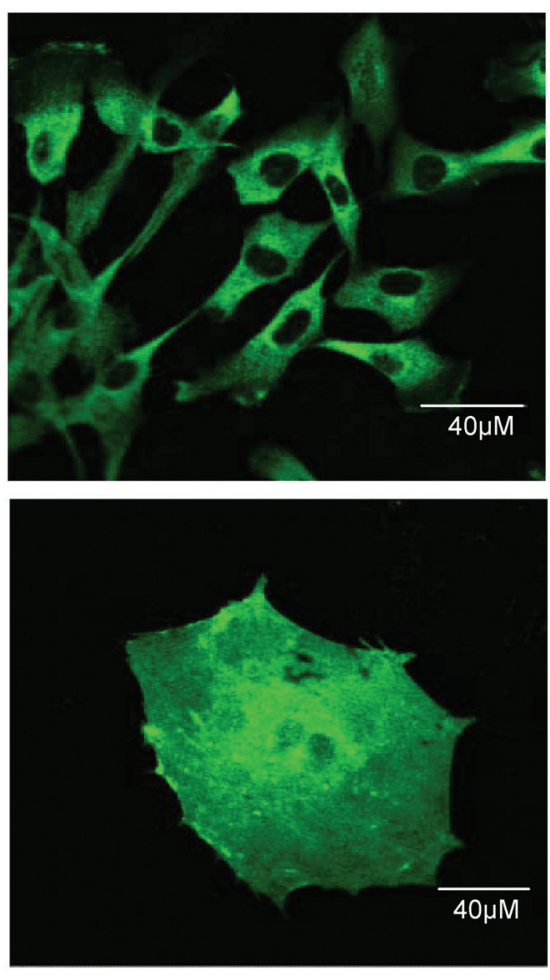

VE-Cad (HHT1)
PECAM-1 (HHT2)
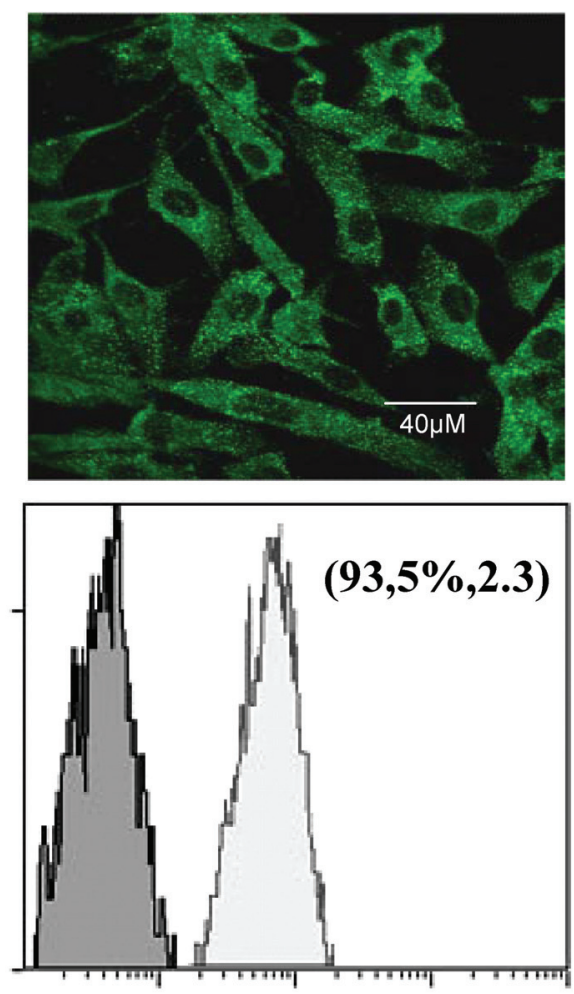

FLK1

Figure 4. BOECs from HHT patients are characterized as endothelial by the expression of specific markers using confocal immunofluorescence microscopy (ALK1, PECAM-1, vWF and VE-Cad) and flow cytometry analyses (VEGFR-2 or Flk-1). The percentage of positive cells $(93.5 \%)$ and the mean fluorescence intensity (2.3) are indicated in the VEGFR-2 histogram. For more detailed information, see Fernández-L et al.75 

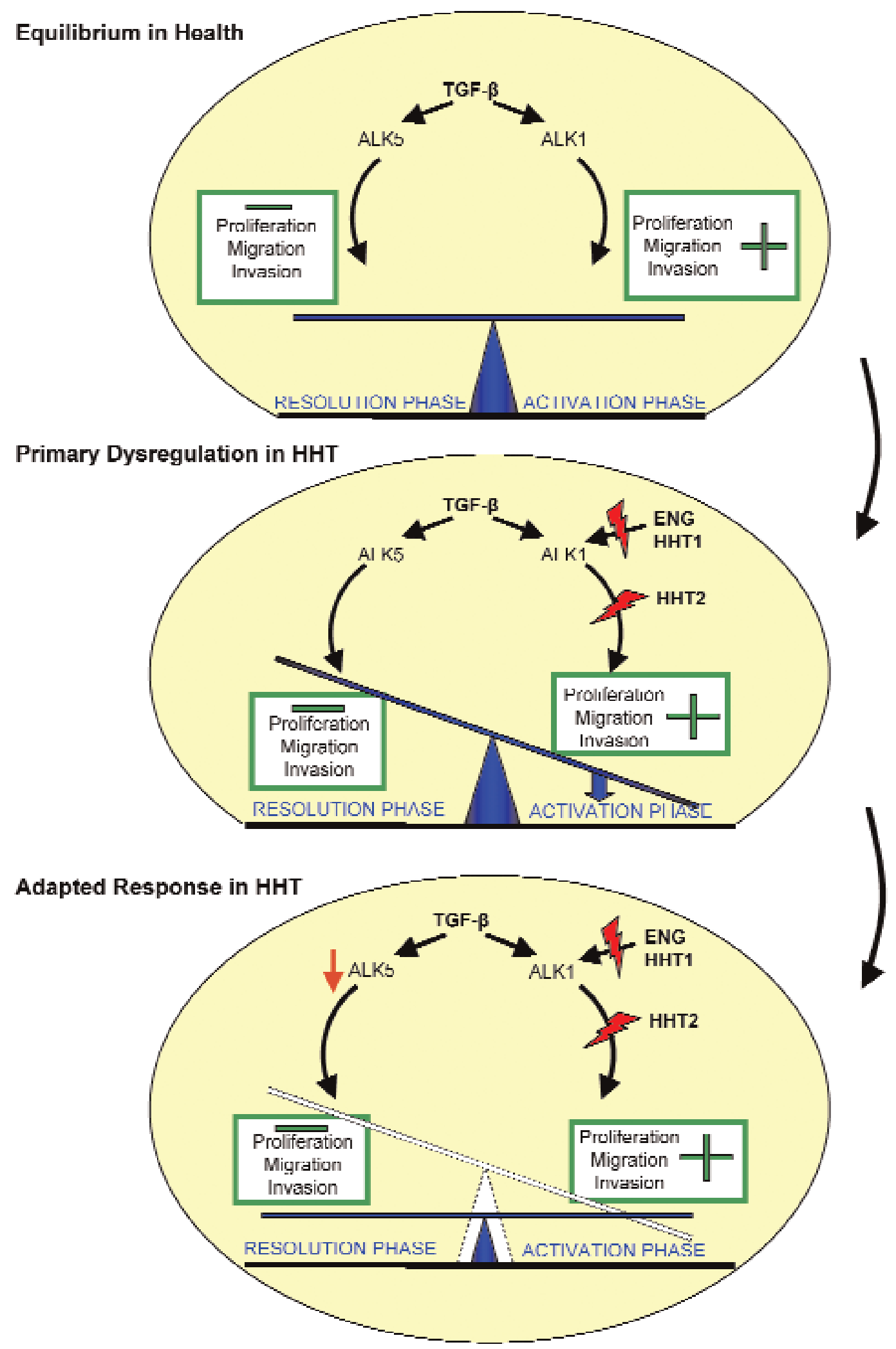

Figure 5. The balanced signaling through TGF- $\beta / A L K 1$ and TGF- $\beta / A L K 5$ in healthy endothelial cells is broken in HHT patients. In HHT1 patients (endoglin mutated), the positive cooperation between endoglin and ALK1 is impaired and the ALK1 signaling pathway is partially abolished. The same is true when ALK1 is mutated in HHT2 patients. Thus, in a primary dysregulation of HHT endothelial cells, proliferation and migration would decrease and, consequently, ALK5 signaling and quiescence would prevail, compromising the angiogenesis process. However, ALK5 levels are decreased in these HHT endothelial cells as part of an adaptive response mechanism. Based on results by Fernández-L et al. ${ }^{75}$ 
stimulated by wild type versions of both $E N G$ and $A L K 1$ and downregulated in HHT cells. ${ }^{76}$ These results suggest that endothelial cells keep a fine balance between $A L K 1 / E N G$ and $A L K 5$ levels, and that mutations in either $E N G$ (HHT1) or $A L K 1$ (HHT2) downregulate ALK5 gene expression to maintain a physiologically adaptive equilibrium between ALK1 and ALK5 routes (figure 5). Otherwise, ALK1 and endoglin mutations would allow the increase of the endothelial cell competitor TGF- $\beta$ /ALK5 pathway, leading to a stop in cell division incompatible with angiogenesis.

\section{Disruption of Angiogenesis: Abnormal Tube Formation in HHT Endothelial Cells}

The TGF- $\beta / A L K 1 /$ endoglin pathway induces proliferation, migration, and tube formation of endothelial cells. One of the predictions of a decreased TGF- $\beta / A L K 1 /$ endoglin pathway in HHT endothelial cells, is the possible interference of building up cord-like structures during the angiogenic process. In fact, in vitro experiments have shown that while normal donor HUVECs and BOECs form robust cord-like structures, HHT BOECs display deficient tube formation. Poorly defined cord structures in HHT1, weak and thin tube-network in null HHT2 or forming cell clusters with abundant sprouting in some missense HHT2 BOECs has been observed (figure 6). As endoglin and ALK1 collaborate in the TGF- $\beta / A L K 1 /$ endoglin pathway leading to the formation of cord-like structures, it is inferred that levels of endoglin or ALK1 below a critical threshold hamper the proper tube formation during the angiogenic process.

\section{Altered F-Actin Cytoskeleton in HHT BOECs}

In addition to the role of endoglin as an auxiliary TGF- $\beta$ receptor, the cytoplasmic domain of endoglin has a role in the organization of the actin cytoskeleton via its binding activity to proteins of the zyxin family (ZRP-1 and zyxin) and associated adaptor proteins. ${ }^{80,81}$ Since HHT1 and HHT2 endothelial cells have a significant decrease in the amount of endoglin in common, one would expect deficiencies in the F-actin cytoskeleton of HHT endothelial cells. Normal endothelial cells are characterized by a highly organized cytoskeleton with stress fibers crossing the entire cell. By contrast, the abnormal shape of HHT BOECs is correlated to an abnormal organization of actin fibers. HHT1 BOECs show a disorganized and depolymerized cytoskeleton, giving rise to very intricate and curious patterns with different foci of actin polymerization. HHT2 BOECs also show a poor organization of the actin cytoskeleton with extensive areas of depolymerization (figure 7). The origin of the altered F-actin polymerization is dependent on endoglin levels since suppression by endoglin-specific small interference RNA in control BOECs leads to a disruption of the actin cytoskeleton. Conversely, overexpression of endoglin in HHT1 cells significantly restores the actin network. ${ }^{76}$

\section{Conclusions}

A common feature of HHT mutations in either $A L K 1$ or $E N G$ is an endoglin deficiency in endothelial cells. ${ }^{76}$ This raises
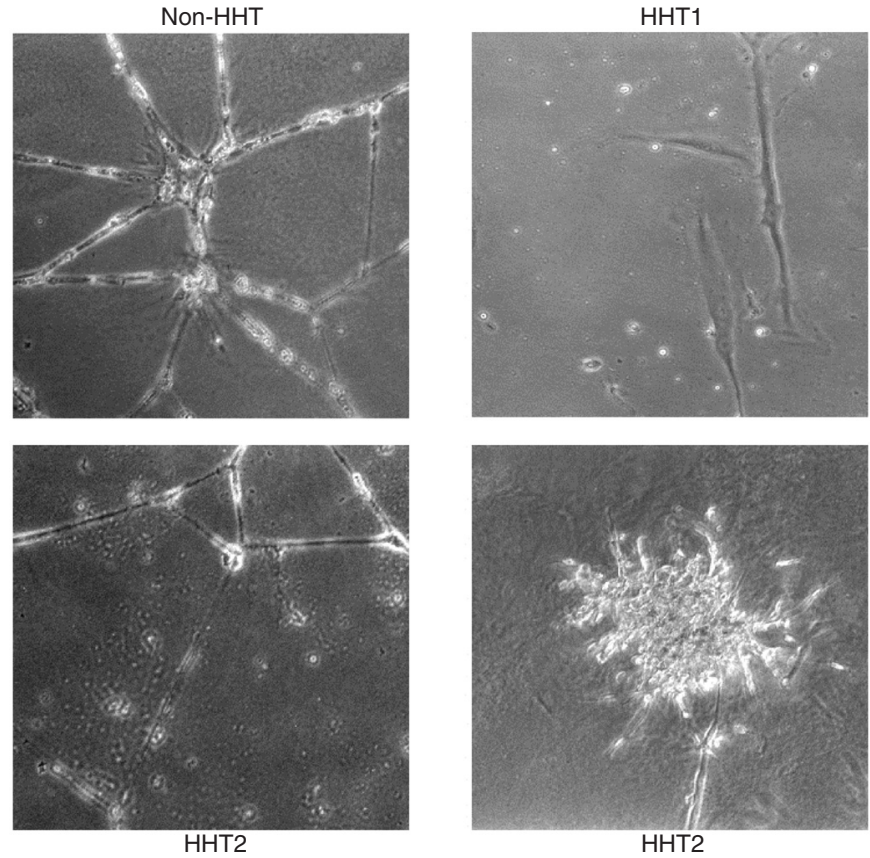

Figure 6. In vitro tube formation assay in BOECs from healthy donors (control) and HHT1 or HHT2 patients. Overall, the tube formation process is incomplete, abnormal or non-existent in HHT BOECs, as compared to control cells. For further details, see Fernández-L et al. ${ }^{75}$
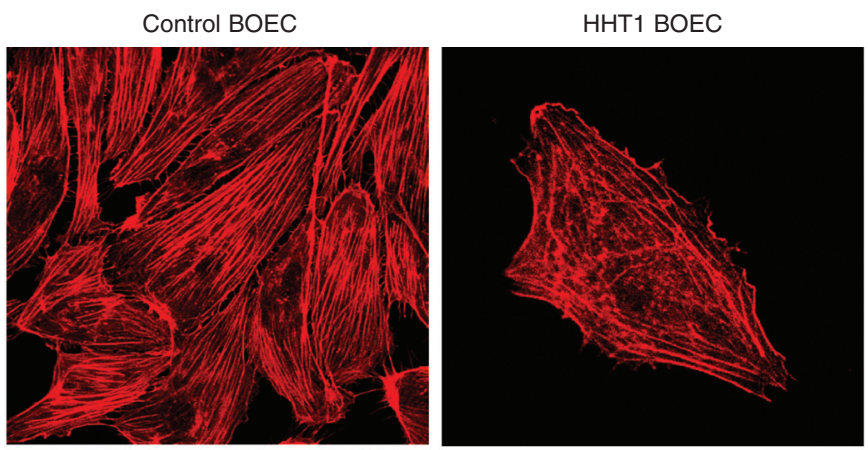

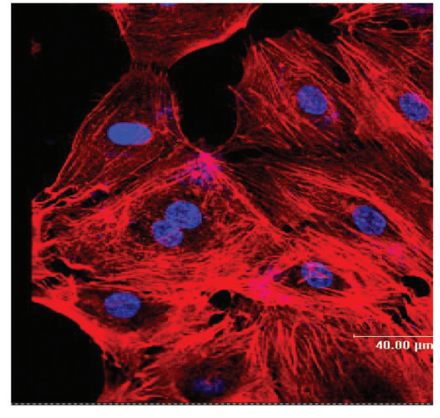

HHT2 BOEC

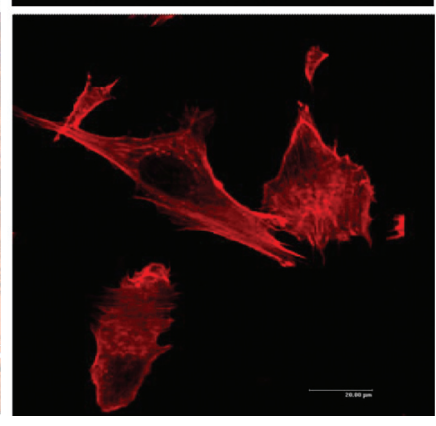

HHT2 BOEC
Figure 7. The actin cytoskeleton is disrupted in HHT BOECs. F-actin cytoskeletons were stained in BOECs from healthy donors (control) and HHT1 or HHT2 patients. While control cells display a perfectly arranged cytoskeleton consisting of stress fibers crossing the entire cell surface, HHT BOECs show actin fibers that do not cross the whole surface and are partially depolymerized or disorganized. For further details see Fernández-L et al. ${ }^{75}$ 


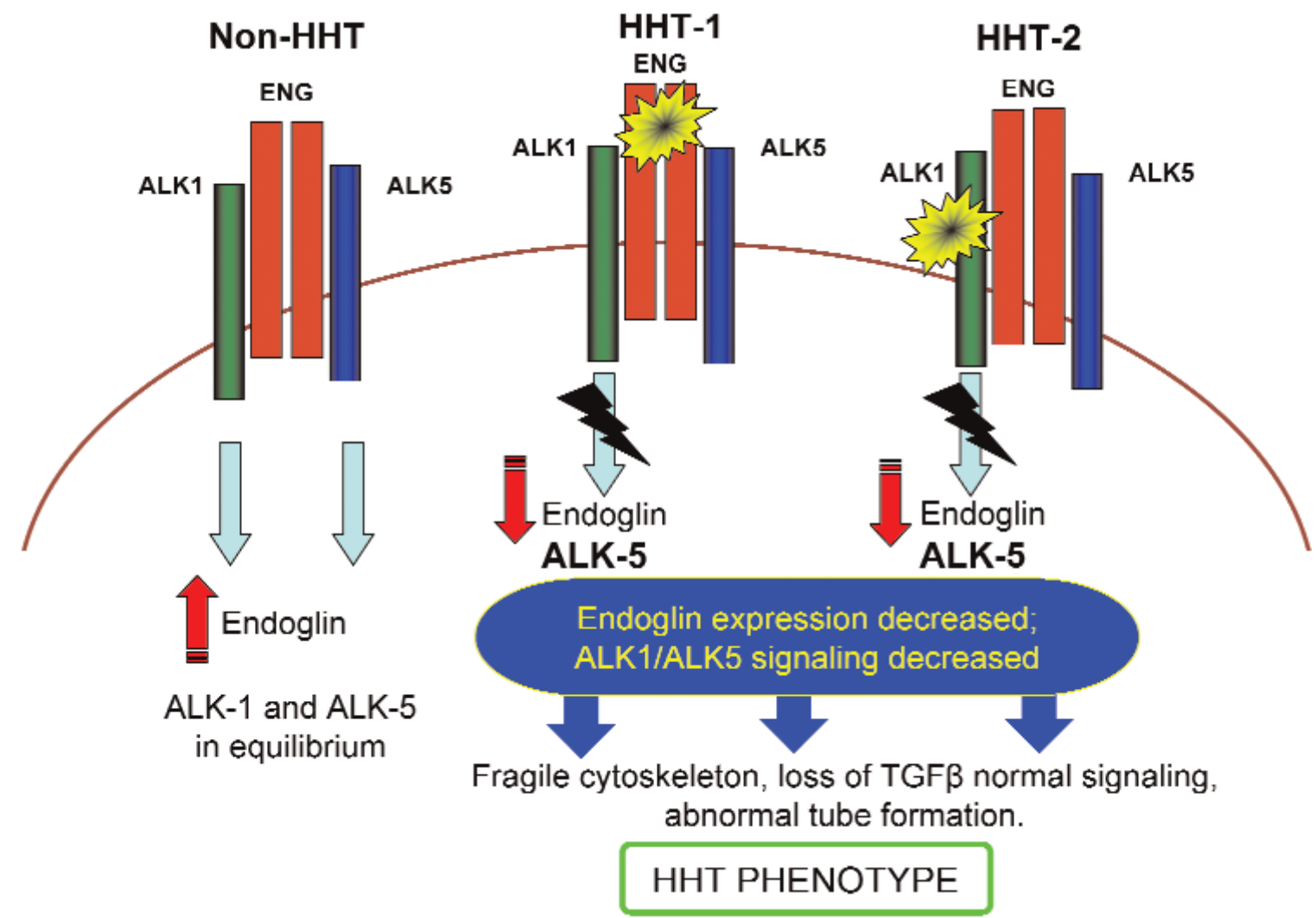

Figure 8. Hypothetical model for HHT. Model representing TGF- $\beta$ receptor complex in healthy (non-HHT) endothelial cells as compared to HHT1 and HHT2 endothelial cells. In healthy endothelial cells (non-HHT), ALK1 and endoglin are cooperating in the TGF- $\beta$ /Smad pathway, and endoglin levels are maintained to meet the physiological needs of the endothelial cell. However, in HHT1 and HHT2 cells, either endoglin or ALK1 fail in the cooperative signaling. As a result, endoglin expression decreases below a critical threshold leading to impaired TGF- $\beta$ signaling, and abnormal cytoskeleton and tube formation in HHT endothelial cells. These altered endothelial cell functions may explain the HHT phenotype. Adapted from Fernández-L et al. ${ }^{75}$

the interesting possibility that endoglin deficiency below a critical threshold is the ultimate pathogenic trigger, not only in HHT1, but also in HHT2 (figure 8). Supporting this view, both endoglin and ALK1 are components of the same TGF- $\beta$ receptor complex, and despite being structurally and functionally different, they cooperate in the TGF- $\beta$ /ALK1 endothelial pathway. As in endothelial cells, both ALK1- and ALK5-dependent TGF- $\beta$ signaling pathways are active, but an adequate balance must be attained among them. Since ALK1 signaling promotes endothelial cell proliferation and migration, and ALK5 inhibits proliferation and migration and induces extracellular matrix synthesis, both pathways must be regulated within endothelial cells to coordinate the different types of responses that are adequate for each physiological situation. Since the ALK1 pathway is decreased in HHT endothelial cells, a mechanism to promote the concomitant decrease of ALK5 membrane levels is elicited to avoid the inhibition of cell proliferation via ALK5. This regulation is based on direct signals from ALK1 and endoglin to the ALK5 promoter. Further experiments in this line of investigation may help to elucidate the complicated network of regulatory interactions that ultimately lead to a fine tuning among the levels of the signaling components in the TGF- $\beta$ pathway. This tuning requires a physiological adaptation of endothelial cells, presumably reached during the period of differentiation from precursor to mature endothelial cells.

A direct consequence of ALK1/TGF- $\beta$ deficient signaling in HHT cells is the decreased capacity for cell migration to form cord-like structures typical of the angiogenic process leading to dysregulation in the organization of the capillary network parallel to their degree of endoglin deficiency. In addition, the abnormal actin cytoskeleton of HHT BOECs may be connected also with decreased endoglin levels. In fact, the endoglin cytoplasmic domain interacts with the zyxin-related protein ZRP1, which is present at the points of actin polymerization. ${ }^{80}$ Accordingly, the decrease in endoglin levels would disrupt the actin polymerization sites. A disorganized cytoskeleton is prone to cell breaking with changes in shear stress and blood pressure and might lead to vessel hemorrhages and eventually disappearance of the capillary network since cells are unable to form proper vessels, as characteristic of the HHT vascular disorder.

The present knowledge about the critical function of endoglin and ALK1 in endothelial cells and the current haploinsufficiency model suggest that the future therapeutic and/or prophylactic perspectives for HHT should necessarily 
include an increased expression of either endoglin or ALK1. This may be accomplished by 1) cellulogenic replacement therapies of endothelium based on the use of endoglin- or ALK1-transduced BOECs, 2) in vivo gene delivery of ENG or $A L K 1$ using endothelial specific viral or plasmid based expression vectors, or 3 ) the use of different stimuli, including soluble factors (like TGF- $\beta$ ) or drugs capable of inducing the expression/function of endoglin or ALK1.

\section{References}

1. Shovlin CL, Letarte M. Hereditary haemorrhagic telangiectasia and pulmonary arteriovenous malformations: issues in clinical management and review of pathogenic mechanisms. Thorax 1999;54:714-729.

2. Plauchu H, Bideau A. Épidémiologie et constitution d'un registre de population à propos d'une concentration géographique d'une maladie héréditaire rare. Population 1984;4-5:765-786.

3. Kjeldsen AD, Vase P, Green A. Hereditary haemorrhagic telangiectasia: a population-based study of prevalence and mortality in Danish patients. J Intern Med 1999;245:31-39.

4. Jessurun GA, Kamphuis DJ, van der Zande FH, Nossent JC Cerebral arteriovenous malformations in The Netherlands Antilles. High prevalence of hereditary hemorrhagic telangiectasia-related single and multiple cerebral arteriovenous malformations. Clin Neurol Neurosurg 1993;95:193-198.

5. Shovlin CL, Guttmacher AE, Buscarini E, Faughnan ME, Hyland RH, Westermann CJ, Kjeldsen AD, Plauchu H. Diagnostic criteria for hereditary hemorrhagic telangiectasia (Rendu-Osler-Weber syndrome). Am J Med Genet 2000;91:66-67.

6. Cohen JH, Faughnan ME, Letarte M, Vandezande K, Kennedy SJ, Krahn MD. Cost comparison of genetic and clinical screening in families with hereditary hemorrhagic telangiectasia. Am J Med Genet A 2005;137:153-160.

7. Plauchu H, de Chadarevian JP, Bideau A, Robert JM. Age-related clinical profile of hereditary hemorrhagic telangiectasia in an epidemiologically recruited population. Am J Med Genet 1989;32:291-297.

8. Porteous ME, Curtis A, Williams O, Marchuk D, Bhattacharya SS, Burn J. Genetic heterogeneity in hereditary haemorrhagic telangiectasia. J Med Genet 1994;31:925-926.

9. Guttmacher AE, Marchuk DA, White RI Jr. Hereditary hemorrhagic telangiectasia. N Engl J Med 1995;333:918924.

10. McDonald MT, Papenberg KA, Ghosh S, Glatfelter AA, Biesecker BB, Helmbold EA, Markel DS, Zolotor A, McKinnon WC, Vanderstoep JL, Jackson CE, Iannuzzi M, Collins FS, Boehnke M, Porteous ME, Guttmacher AE, Marchuk DA. A disease locus for hereditary haemorrhagic telangiectasia maps to chromosome $9 \mathrm{q} 33-34$. Nat Genet 1994;6:197-204.

11. Shovlin CL, Hughes JM, Tuddenham EG, Temperley I, Perembelon YF, Scott J, Seidman CE, Seidman JG. A gene for hereditary haemorrhagic telangiectasia maps to chromosome 9q3. Nat Genet 1994;6:205-209.

12. Fernandez-Ruiz E, St-Jacques S, Bellon T, Letarte M, Bernabeu C. Assignment of the human endoglin gene (END) to $9 \mathrm{q} 34 \longrightarrow \mathrm{qter}$. Cytogenet Cell Genet 1993;64:204-207.
13. McAllister KA, Grogg KM, Johnson DW, Gallione CJ, Baldwin MA, Jackson CE, Helmbold EA, Markel DS, McKinnon WC, Murrell J, McCormick MK, Pericak-Vance MA, Heutink P, Oostra BA, Haitjema T, Westerman CJ, Porteous ME, Guttmacher AE, Letarte M, Marchuk DA. Endoglin, a TGF-beta binding protein of endothelial cells, is the gene for hereditary haemorrhagic telangiectasia type 1. Nat Genet 1994;8:345-351.

14. Johnson DW, Berg JN, Baldwin MA, Gallione CJ, Marondel I, Yoon SJ, Stenzel TT, Speer M, Pericak-Vance MA, Diamond A, Guttmacher AE, Jackson CE, Attisano L, Kucherlapati R, Porteous ME, Marchuk DA. Mutations in the activin receptor-like kinase 1 gene in hereditary haemorrhagic telangiectasia type 2. Nat Genet 1996;13:189-195.

15. Buscarini E, Buscarini L, Danesino C, Piantanida M, Civardi G, Quaretti P, Rossi S, Di Stasi M, Silva M. Hepatic vascular malformations in hereditary hemorrhagic telangiectasia: Doppler sonographic screening in a large family. J Hepatol 1997;26:111-118.

16. Wallace GM, Shovlin CL. A hereditary haemorrhagic telangiectasia family with pulmonary involvement is unlinked to the known HHT genes, endoglin and ALK-1. Thorax 2000;55:685-690.

17. Trembath RC, Thomson JR, Machado RD, Morgan NV, Atkinson C, Winship I, Simonneau G, Galie N, Loyd JE, Humbert M, Nichols WC, Morrell NW, Berg J, Manes A, McGaughran J, Pauciulo M, Wheeler L. Clinical and molecular genetic features of pulmonary hypertension in patients with hereditary hemorrhagic telangiectasia. N Engl J Med 2001;345:325-334.

18. Harrison RE, Flanagan JA, Sankelo M, Abdalla SA, Rowell J, Machado RD, Elliott CG, Robbins IM, Olschewski H, McLaughlin V, Gruenig E, Kermeen F, Halme M, Raisanen-Sokolowski A, Laitinen T, Morrell NW, Trembath RC. Molecular and functional analysis identifies ALK-1 as the predominant cause of pulmonary hypertension related to hereditary haemorrhagic telangiectasia. J Med Genet 2003;40:865-871.

19. Abdalla SA, Gallione CJ, Barst RJ, Horn EM, Knowles JA, Marchuk DA, Letarte M, Morse JH. Primary pulmonary hypertension in families with hereditary haemorrhagic telangiectasia. Eur Respir J 2004;23:373-377.

20. Gallione CJ, Repetto GM, Legius E, Rustgi AK, Schelley SL, Tejpar S, Mitchell G, Drouin E, Westermann CJ, Marchuk DA. A combined syndrome of juvenile polyposis and hereditary haemorrhagic telangiectasia associated with mutations in MADH4 (SMAD4). Lancet 2004;363:852-859.

21. Cole SG, Begbie ME, Wallace GM, Shovlin CL. A new locus for hereditary haemorrhagic telangiectasia (HHT3) maps to chromosome 5. J Med Genet 2005;42:577-582.

22. Berg JN, Gallione CJ, Stenzel TT, Johnson DW, Allen WP, Schwartz CE, Jackson CE, Porteous ME, Marchuk DA. The activin receptor-like kinase 1 gene: genomic structure and mutations in hereditary hemorrhagic telangiectasia type 2 . Am J Hum Genet 1997;61:60-67.

23. Abdalla SA, Pece-Barbara N, Vera S, Tapia E, Paez E, Bernabeu C, Letarte M. Analysis of ALK-1 and endoglin in newborns from families with hereditary hemorrhagic telangiectasia type 2. Hum Mol Genet 2000;9:1227-1237.

24. Olivieri C, Mira E, Delu G, Pagella F, Zambelli A, Malvezzi L, Buscarini E, Danesino C. Identification of 13 new mutations in the ACVRL1 gene in a group of 52 unselected Italian patients affected by hereditary haemorrhagic telangiectasia. J Med Genet 2002;39:E39.

25. Abdalla SA, Geisthoff UW, Bonneau D, Plauchu H, McDonald J, Kennedy S, Faughnan ME, Letarte M. Visceral manifestations in hereditary haemorrhagic telangiectasia type 2. J Med Genet 2003;40:494-502. 
26. Letteboer TG, Zewald RA, Kamping EJ, de Haas G, Mager JJ, Snijder RJ, Lindhout D, Hennekam FA, Westermann CJ, Ploos van Amstel JK. Hereditary hemorrhagic telangiectasia: ENG and ALK-1 mutations in Dutch patients. Hum Genet 2005;116:8-16.

27. Lastella P, Sabba C, Lenato GM, Resta N, Lattanzi W, Gallitelli M, Cirulli A, Guanti G. Endoglin gene mutations and polymorphisms in Italian patients with hereditary haemorrhagic telangiectasia. Clin Genet 2003;63:536-540.

28. Lesca G, Plauchu H, Coulet F, Lefebvre S, Plessis G, Odent S, Riviere S, Leheup B, Goizet C, Carette MF, Cordier JF, Pinson S, Soubrier F, Calender A, Giraud S; French Rendu-Osler Network. Molecular screening of ALK1/ACVRL1 and ENG genes in hereditary hemorrhagic telangiectasia in France. Hum Mutat 2004;23:289-299.

29. Fernández-L A, Sanz-Rodriguez F, Zarrabeitia R, Perez-Molino A, Morales C, Restrepo CM, Ramirez JR, Coto E, Lenato GM, Bernabeu C, Botella LM. Mutation study of Spanish patients with hereditary hemorrhagic telangiectasia and expression analysis of Endoglin and ALK1. Hum Mutat 2006;27:295.

30. Abdalla SA, Letarte M. Hereditary haemorrhagic telangiectasia: current views on genetics and mechanisms of disease. J Med Genet 2006;43:97-110. Epub 2005 May 6.

31. Cymerman U, Vera S, Karabegovic A, Abdalla S, Letarte M. Characterization of 17 novel endoglin mutations associated with hereditary hemorrhagic telangiectasia. Hum Mutat 2003;21:482-492.

32. Abdalla SA, Cymerman U, Johnson RM, Deber CM, Letarte M. Disease-associated mutations in conserved residues of ALK-1 kinase domain. Eur J Hum Genet 2003;11:279-287.

33. ten Dijke P, Hill CS. New insights into TGF-beta-Smad signalling. Trends Biochem Sci 2004;29:265-273.

34. Yamashita H, ten Dijke P, Franzen P, Miyazono K, Heldin CH. Formation of hetero-oligomeric complexes of type I and type II receptors for transforming growth factor-beta. J Biol Chem 1994;269:20172-20178.

35. Wrana JL, Attisano L, Wieser R, Ventura F, Massague J. Mechanism of activation of the TGF-beta receptor. Nature 1994;370:341-347.

36. Derynck R, Zhang YE. Smad-dependent and Smad-independent pathways in TGF-beta family signalling. Nature 2003;425:577-584.

37. Nakao A, Imamura T, Souchelnytskyi S, Kawabata M, Ishisaki A, Oeda E, Tamaki K, Hanai J, Heldin CH, Miyazono K, ten Dijke P. TGF-beta receptor-mediated signalling through Smad2, Smad3 and Smad4. EMBO J 1997;16:5353-5362.

38. Suzuki C, Murakami G, Fukuchi M, Shimanuki T, Shikauchi Y, Imamura T, Miyazono K. Smurf1 regulates the inhibitory activity of Smad7 by targeting Smad7 to the plasma membrane. J Biol Chem 2002;277:39919-39925.

39. Shi W, Sun C, He B, Xiong W, Shi X, Yao D, Cao X. GADD34-PP1c recruited by Smad7 dephosphorylates TGFbeta type I receptor. J Cell Biol 2004;164:291-300.

40. Cheifetz S, Bellon T, Cales C, Vera S, Bernabeu C, Massague J, Letarte M. Endoglin is a component of the transforming growth factor-beta receptor system in human endothelial cells. J Biol Chem 1992;267:19027-19030.

41. Barbara NP, Wrana JL, Letarte M. Endoglin is an accessory protein that interacts with the signaling receptor complex of multiple members of the transforming growth factor-beta superfamily. J Biol Chem 1999;274:584-594.

42. Letamendia A, Lastres P, Botella LM, Raab U, Langa C, Velasco B, Attisano L, Bernabeu C. Role of endoglin in cellular responses to transforming growth factor-beta. A comparative study with betaglycan. J Biol Chem 1998;273:33011-33019.
43. Guerrero-Esteo M, Sanchez-Elsner T, Letamendia A, Bernabeu C. Extracellular and cytoplasmic domains of endoglin interact with the transforming growth factor-beta receptors I and II. J Biol Chem 2002;277:29197-29209.

44. Lebrin F, Goumans MJ, Jonker L, Carvalho RL, Valdimarsdottir G, Thorikay M, Mummery C, Arthur HM, ten Dijke P. Endoglin promotes endothelial cell proliferation and TGF-beta/ALK1 signal transduction. EMBO J 2004;23:4018-4028.

45. Blanco FJ, Santibanez JF, Guerrero-Esteo M, Langa C, Vary $\mathrm{CP}$, Bernabeu C. Interaction and functional interplay between endoglin and ALK-1, two components of the endothelial transforming growth factor-beta receptor complex. J Cell Physiol 2005;204:574-584.

46. Goumans MJ, Valdimarsdottir G, Itoh S, Rosendahl A, Sideras $\mathrm{P}$, ten Dijke P. Balancing the activation state of the endothelium via two distinct TGF-beta type I receptors. EMBO J 2002;21:1743-1753.

47. Goumans MJ, Lebrin F, Valdimarsdottir G. Controlling the angiogenic switch: a balance between two distinct TGF-b receptor signaling pathways. Trends Cardiovasc Med 2003;13:301-307.

48. Oh SP, Seki T, Goss KA, Imamura T, Yi Y, Donahoe PK, Li L, Miyazono K, ten Dijke P, Kim S, Li E. Activin receptor-like kinase 1 modulates transforming growth factor-beta 1 signaling in the regulation of angiogenesis. Proc Natl Acad Sci U S A 2000;97:2626-2631.

49. Lebrin F, Deckers M, Bertolino P, Ten Dijke P. TGF-beta receptor function in the endothelium. Cardiovasc Res 2005;65:599-608.

50. van den Driesche S, Mummery CL, Westermann CJ. Hereditary hemorrhagic telangiectasia: an update on transforming growth factor beta signaling in vasculogenesis and angiogenesis. Cardiovasc Res 2003;58:20-31.

51. Begbie ME, Wallace GM, Shovlin CL. Hereditary haemorrhagic telangiectasia (Osler-Weber-Rendu syndrome): a view from the 21 st century. Postgrad Med J 2003;79:18-24.

52. Stefansson S, Petitclerc E, Wong MK, McMahon GA, Brooks $\mathrm{PC}$, Lawrence DA. Inhibition of angiogenesis in vivo by plasminogen activator inhibitor-1. J Biol Chem 2001;276:8135-8141.

53. Karabegovic A, Shinawi M, Cymerman U, Letarte M. No live individual homozygous for a novel endoglin mutation was found in a consanguineous Arab family with hereditary haemorrhagic telangiectasia. J Med Genet 2004;41:e119.

54. Li DY, Sorensen LK, Brooke BS, Urness LD, Davis EC, Taylor DG, Boak BB, Wendel DP. Defective angiogenesis in mice lacking endoglin. Science 1999;284:1534-1537.

55. Bourdeau A, Dumont DJ, Letarte M. A murine model of hereditary hemorrhagic telangiectasia. J Clin Invest 1999;104:1343-1351.

56. Bourdeau A, Faughnan ME, Letarte M. Endoglin-deficient mice, a unique model to study hereditary hemorrhagic telangiectasia. Trends Cardiovasc Med 2000;10:279-285.

57. Arthur HM, Ure J, Smith AJ, Renforth G, Wilson DI, Torsney E, Charlton R, Parums DV, Jowett T, Marchuk DA, Burn J, Diamond AG. Endoglin, an ancillary TGF beta receptor, is required for extraembryonic angiogenesis and plays a key role in heart development. Dev Biol 2000;217:42-53.

58. McAllister KA, Baldwin MA, Thukkani AK, Gallione CJ, Berg JN, Porteous ME, Guttmacher AE, Marchuk DA. Six novel mutations in the endoglin gene in hereditary hemorrhagic telangiectasia type 1 suggest a dominant-negative effect of receptor function. Hum Mol Genet 1995;4:1983-1985.

59. Shovlin CL, Hughes JM, Scott J, Seidman CE, Seidman JG. Characterization of endoglin and identification of novel mutations in hereditary hemorrhagic telangiectasia. Am J Hum Genet 1997;61:68-79. 
60. Gallione CJ, Klaus DJ, Yeh EY, Stenzel TT, Xue Y, Anthony KB, McAllister KA, Baldwin MA, Berg JN, Lux A, Smith JD, Vary CP, Craigen WJ, Westermann CJ, Warner ML, Miller YE, Jackson CE, Guttmacher AE, Marchuk DA. Mutation and expression analysis of the endoglin gene in hereditary hemorrhagic telangiectasia reveals null alleles. Hum Mutat 1998;11:286-294.

61. Pece N, Vera S, Cymerman U, White RI Jr, Wrana JL, Letarte M. Mutant endoglin in hereditary hemorrhagic telangiectasia type 1 is transiently expressed intracellularly and is not a dominant negative. J Clin Invest 1997;100:2568-2579.

62. Raab U, Velasco B, Lastres P, Letamendia A, Cales C, Langa C, Tapia E, Lopez-Bote JP, Paez E, Bernabeu C. Expression of normal and truncated forms of human endoglin. Biochem $\mathrm{J}$ 1999;339:579-588.

63. Paquet ME, Pece-Barbara N, Vera S, Cymerman U, Karabegovic A, Shovlin C, Letarte M. Analysis of several endoglin mutants reveals no endogenous mature or secreted protein capable of interfering with normal endoglin function. Hum Mol Genet 2001;10:1347-1357.

64. Cymerman U, Vera S, Pece-Barbara N, Bourdeau A, White RI Jr, Dunn J, Letarte M. Identification of hereditary hemorrhagic telangiectasia type 1 in newborns by protein expression and mutation analysis of endoglin. Pediatr Res 2000;47:24-35.

65. Lux A, Attisano L, Marchuk DA. Assignment of transforming growth factor beta1 and beta3 and a third new ligand to the type I receptor ALK-1. J Biol Chem 1999;274:9984-9992.

66. Urness LD, Sorensen LK, Li DY. Arteriovenous malformations in mice lacking activin receptor-like kinase-1. Nat Genet 2000;26:328-331.

67. Srinivasan S, Hanes MA, Dickens T, Porteous ME, Oh SP, Hale LP, Marchuk DA. A mouse model for hereditary hemorrhagic telangiectasia (HHT) type 2. Hum Mol Genet 2003;12:473-482.

68. Carvalho RL, Jonker L, Goumans MJ, Larsson J, Bouwman P, Karlsson S, Dijke PT, Arthur HM, Mummery CL. Defective paracrine signalling by TGFbeta in yolk sac vasculature of endoglin mutant mice: a paradigm for hereditary haemorrhagic telangiectasia. Development 2004;131:6237-6247.

69. Bourdeau A, Faughnan ME, McDonald ML, Paterson AD, Wanless IR, Letarte M. Potential role of modifier genes influencing transforming growth factor-betal levels in the development of vascular defects in endoglin heterozygous mice with hereditary hemorrhagic telangiectasia. Am J Pathol 2001;158:2011-2020.

70. Torsney E, Charlton R, Diamond AG, Burn J, Soames JV, Arthur HM. Mouse model for hereditary hemorrhagic telangiectasia has a generalized vascular abnormality. Circulation 2003;107:1653-1657.

71. Velasco B, Ramirez JR, Relloso M, Li C, Kumar S, Lopez-Bote JP, Perez-Barriocanal F, Lopez-Novoa JM, Cowan PJ, d'Apice AJ, Bernabeu C. Vascular gene transfer driven by endoglin and ICAM-2 endothelial-specific promoters. Gene Ther 2001;8:897-904.

72. Lastres P, Bellon T, Cabanas C, Sanchez-Madrid F, Acevedo A, Gougos A, Letarte M, Bernabeu C. Regulated expression on human macrophages of endoglin, an Arg-Gly-Asp-containing surface antigen. Eur J Immunol 1992;22:393-397.

73. Sanz-Rodriguez F, Fernandez-L A, Zarrabeitia R, Perez-Molino A, Ramirez JR, Coto E, Bernabeu C, Botella LM. Mutation analysis in Spanish patients with hereditary hemorrhagic telangiectasia: deficient endoglin up-regulation in activated monocytes. Clin Chem 2004;50:2003-2011.

74. Lin Y, Weisdorf DJ, Solovey A, Hebbel RP. Origins of circulating endothelial cells and endothelial outgrowth from blood. J Clin Invest 2000;105:71-77.
75. Lin Y, Chang L, Solovey A, Healey JF, Lollar P, Hebbel RP. Use of blood outgrowth endothelial cells for gene therapy for hemophilia A. Blood 2002;99:457-462.

76. Fernandez-L A, Sanz-Rodriguez F, Zarrabeitia R, Perez-Molino A, Hebbel RP, Nguyen J, Bernabeu C, Botella LM. Blood outgrowth endothelial cells from hereditary haemorrhagic telangiectasia patients reveal abnormalities compatible with vascular lesions. Cardiovasc Res 2005;68:235-248.

77. Rius C, Smith JD, Almendro N, Langa C, Botella LM, Marchuk DA, Vary CP, Bernabeu C. Cloning of the promoter region of human endoglin, the target gene for hereditary hemorrhagic telangiectasia type 1. Blood 1998;92:4677-4690.

78. Botella LM, Sanchez-Elsner T, Rius C, Corbi A, Bernabeu C. Identification of a critical Spl site within the endoglin promoter and its involvement in the transforming growth factor-beta stimulation. J Biol Chem 2001;276:34486-34494.

79. Pece-Barbara N, Vera S, Kathirkamathamby K, Liebner S, Di Guglielmo GM, Dejana E, Wrana JL, Letarte M. Endoglin null endothelial cells proliferate faster and are more responsive to transforming growth factor beta1 with higher affinity receptors and an activated Alk1 pathway. J Biol Chem 2005;280:27800-27808.

80. Sanz-Rodriguez F, Guerrero-Esteo M, Botella LM, Banville D, Vary CP, Bernabeu C. Endoglin regulates cytoskeletal organization through binding to ZRP-1, a member of the Lim family of proteins. J Biol Chem 2004;279:32858-32868.

81. Conley BA, Koleva R, Smith JD, Kacer D, Zhang D, Bernabeu C, Vary CP. Endoglin controls cell migration and composition of focal adhesions: function of the cytosolic domain. J Biol Chem 2004;279:27440-27449.

\section{Author Affiliations}

Africa Fernández-L, Predoctoral fellow; Centro de Investigaciones Biologicas (CSIC); Ramiro de Maeztu, 9; Madrid 28040; Spain.

Francisco Sanz-Rodriguez, PhD; Departamento de Biología, Universidad Autónoma, Madrid, Spain.

Francisco J. Blanco, Predoctoral fellow; Centro de Investigaciones Biologicas (CSIC); Ramiro de Maeztu, 9; Madrid 28040; Spain.

Carmelo Bernabéu, PhD; Centro de Investigaciones Biologicas (CSIC); Ramiro de Maeztu, 9; Madrid 28040; Spain.

Luisa M. Botella, PhD; Centro de Investigaciones Biologicas (CSIC); Ramiro de Maeztu, 9; Madrid 28040; Spain. 